Georgetown University Law Center

Scholarship @ GEORGETOWN LAW

2012

\title{
The Legal Significance of the Psychological Ability to Appreciate the "Other"
}

Paul F. Rothstein

Georgetown University Law Center, rothstei@law.georgetown.edu

This paper can be downloaded free of charge from:

https://scholarship.law.georgetown.edu/facpub/1417

http://ssrn.com/abstract=2539562

1 J. C. \& Legal Sci. (2012)

This open-access article is brought to you by the Georgetown Law Library. Posted with permission of the author. Follow this and additional works at: https://scholarship.law.georgetown.edu/facpub

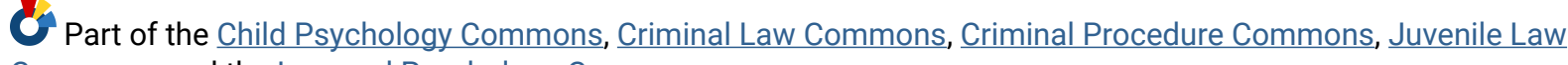
Commons, and the Law and Psychology Commons 


\title{
The Legal Significance of the Psychological Ability to Appreciate the "Other"
}

\author{
Paul F Rothstein*
}

Recently the U.S. Supreme Court, citing neurological and psychological studies, held that because juveniles are deficient in appreciating consequences to others, they should never be given the death penalty. I have become convinced, in my years as a legal scholar, educator, and practitioner, that "appreciating the 'other"'-putting oneself in the position of others--is critical to law and the study of law in more than the obvious ways.

Years ago I became aware of empirical studies and psychological experiments demonstrating that children below a certain age have trouble seeing things from another's vantage point. The facility to do so develops gradually with age, but more in some people than others.

One experiment (which I simplify here) simultaneously exposed two children (child 1 and 2) to a ball being placed in box A. of a series of boxes on a table. It was done in the sight of both children. Then, in the sight of child 1, child 2 was removed from the room. Then, in the sight of child 1, but not in the sight of child 2, the ball was removed from box A. and put in box B. Child 1 was then asked which box child 2 would say the ball was in. Although child 1 saw that child 2 had not seen the change of the location of the ball to box B., child 1 said child 2 would know the ball was in box B (as child 1 knew). Child 1 was unable to comprehend that child 2, as a separate person from child 1 , had different information than child 1 . This led me to think of children I know, who think if they close their eyes, I can't see them. Those children, and child 1 in the experiment, and perhaps some adults, lack or have muted ability to "view things from another's shoes". This may be called lack of empathy, in some contexts.

As I read these and other studies, I became confirmed in my belief that the ability to appreciate the vantage point and informational position of others is central to a wide range of concepts in the law.

The law often requires a distinction between what you yourself would do or think, and what others would do or think. The idea of "reasonable"-key to many areas of law--implies that you may think something is wrong but not necessarily unreasonable (i.e., that other people you regard as reasonable might think differently).

This notion of "reasonableness" is inherent in negligence law, which punishes conduct which a jury finds to be "unreasonable," i.e., conduct which the jury finds a "reasonable person" (who was in the same circumstances as defendant was in at the time of taking the action) would not have engaged in. This judgment by the jury is not to be made in hindsight. If the jury, lawyers, and judges understand the vantage-point difference discussed above, they will do a much better job in negligence cases than if they do not. And law students who understand it will better comprehend negligence law.

*Professor, Faculty of Law, Georgetown University, Law Center, Washington DC, USA 
Further, to the extent judges master the facility to put themselves in the shoes of others, the more effectively they will be able to faithfully perform what the law commands them to do when deciding whether the facts warrant taking a case from (or overruling) the jury-i.e. when deciding motions for summary judgment, dismissal, directed verdict, judgment notwithstanding the verdict, etc.; or when deciding what to do in reviewing a lower court judge's rulings. In each case, the judge is commanded to be deferential and is not supposed to substitute her own decision for that of the other (the jury or lower court judge) unless the decision of the other is or would be "unreasonable," which the judge should understand is different from what she, the judge, thinks is a "wrong" decision. The same deference should normally be accorded by reviewing judges to the decisions of administrative agencies as well.

"Qualified immunity" of public officials and police is another area where "reasonableness" plays a large role, particularly in Section 1983 civil-rights-violation lawsuits. The concept of "reasonable" (as opposed to "right" or "wrong") is key in this area - there is no immunity if a reasonable public official would have known what he/she was doing was a violation of a "clearly established" constitutional right. If the violation alleged is in the search and seizure area, the concept of "reasonable" may come in twice in the analysis: once in computing whether there was a constitutional violation--was the search "reasonable"?--and once in deciding whether, even if it was unreasonable, a "reasonable" officer would have known it. In these areas, "reasonable" entails the same suppression of one's own view as indicated above.

A similar concept has been applied on review in habeas corpus and other collateral attacks on judicial rulings in other areas - the question asked in these cases, is, was there an "unreasonable" (not just "incorrect") interpretation of a clearly established constitutional right?

Perhaps most importantly to our role as legal educators, a student's success in law school depends upon understanding deeply this separation between self and others and appreciation of the difference of vantage point. As indicated above, negligence law, judge-jury relations, appellate review, judicial review of administrative agencies, and other areas of law, will all be better understood by the student if this separation is mastered. And functioning as an advocate - whether one is a practicing lawyer or just learning to be one--necessarily involves a real appreciation that the other side, or the judge, jury, or other decision maker, may well see things diametrically differently than you are convinced they are. So does writing an answer to a legal exam. In all these contexts, you have to be prepared for the arguments on the other side. One of the biggest surprises encountered in practice by young lawyers, is that the other sideand even the judge or jury - may see something in a way that was totally foreign to what the young lawyer thought was as "plain as the nose on your face". Legal educators are quite familiar with the student who can see things his/her way only. Most first year law students start out like this, at the beginning of their law studies, and must be taught to strive to also see things as others see them.

In a sense, the function of law in a democracy is to recognize, harmonize and accommodate that others may have different views than yourself. I think the ability to put one in the shoes of others is critical, and I will - as a long range interest of mine--be exploring more fully the implications of this for the law and our society as far as I am able within the areas of my competence. I aim to verify my initial intuitions and ascertain more completely where and how 
the ability to appreciate the "other" interfaces with the law. And I intend to continue to search for and investigate psychological or empirical studies that may shed some light on this. For example, a recent neurological study by one of my "alma maters", Oxford University, finds there is a portion of the brain that is more highly developed in people who have many "friends". This may have something to do with the capacity for empathy that I am interested in.

Even if I ultimately prove my initial intuitions to be false, that might be interesting to write about, too. 